\title{
Pre-Service Language Teachers' Knowledge and Practices of Intercultural Communicative Competence
}

\author{
Conocimiento y prácticas de la competencia comunicativa \\ intercultural de los docentes de lengua en formación
}

\author{
María Teresa Esteban-Núñez ${ }^{1}$
}

\begin{abstract}
This paper reports a descriptive case study developed in an English language teaching program at a public university in Colombia. The purpose of this study was to disclose what knowledge a group of pre-service teachers had about intercultural communicative competence and how they considered their approach to this competence in the English classes they had planned during their final pedagogical practicum. The instruments used to collect data were documents, interviews, and a survey. The outcomes were meaningful for the participants as well as for the researcher since it was possible to identify that pre-service teachers understand this competence as a visible concept to be approached in the classes, mainly to refer to and learn about other cultures different from the Colombian and Boyacense ones. It was also identified that the intercultural communicative competence was considered, by these pre-service teachers, as the "dressing" to change the taste of the class.
\end{abstract} teachers

Keywords: culture, intercultural communicative competence, knowledge, practices, pre-service

\section{Resumen}

Este trabajo reporta un estudio de caso descriptivo desarrollado en un programa de enseñanza en una universidad pública en Colombia. El propósito de este estudio fue el de revelar qué conocimiento tenía un grupo de profesores en formación con respecto a la competencia comunicativa intercultural y cómo ellos consideraban que estaban enfocando esta competencia en las clases propuestas para su

1 She holds a BA in Modern Languages and an MA in Language Teaching from Universidad Pedagógica y Tecnológica de Colombia. She is a full-time teacher-researcher in the undergraduate and postgraduate programs at the same University. She is a member of the research group Knowledge in Action (KIA).

mariateresa.esteban@uptc.edu.co

ORCID ID: https://orcid.org/0000-0002-0339-4821

Received: July 14th, 2020. Accepted: October 23rd, 2020.

This article is licensed under a Creative Commons Attribution-Non-Commercial-No-Derivatives 4.0 International License. License Deed can be consulted at https://creativecommons.org/licenses/by-nc-nd/4.0. 
práctica pedagógica final. Los instrumentos utilizados para recoger la información fueron documentos, entrevistas y una encuesta. Los resultados fueron significativos para los participantes, así como para el investigador, ya que fue posible identificar que los profesores en formación comprenden esta competencia como un concepto visible para ser abordado en las clases, principalmente para referirse y aprender de otras culturas diferentes a la colombiana y la boyacense. También se identificó que la competencia comunicativa intercultural es considerada, por estos profesores en formación, como el "aderezo" para cambiar el sabor de la clase.

Palabras clave: cultura, competencia comunicativa intercultural, maestros en formación, conocimiento, prácticas

\section{Introduction}

This paper reports the description of a study developed in an English language teaching program at a public university in Colombia. The research study aimed to identify and analyze the conceptualization that a group of pre-service teachers held about intercultural communicative competence (ICC henceforth) and their experiences regarding this competence.

The nature of this study relies on the significance that English language has gained around the world, and specifically in Colombia, where the current policies have approached this language as the key to open spaces to interact in the globalized world. Thus, teaching a language goes beyond the linguistic aspects of the language, since learning a language is also learning a culture or learning about multiple and varied cultures. Therefore, language teachers should not be trained to teach only the language in order to develop the communicative competence but also the ICC.

For different authors and theoreticians, such as Byram (1997), Liddicoat (2002), Kramsch (1993), Gómez (2012), and Ramos (2013), among others, ICC cannot be separated from the process of learning a language. In this progressively more globalized world, teachers should create opportunities for the exploration and knowledge of other cultures without leaving their own aside. It is in the classroom where students are best able to discern their cultural knowledge and discover their validity. Under these ideas, teachers change their roles from transmitters of knowledge to become mediators among diverse and multiple cultures. In

12 their role as mediators, they integrate culture as part of their daily lessons, and they display questions and activities in which students not only learn about language but also about cultures as they enhance critical positions towards diverse cultural practices and products.

Therefore, pre-service teachers should understand the need to explore intercultural competence through the development of their classes. However, as a first step to turn this possibility into a reality, the exploration of the knowledge and experience that preservice teachers have about the concept of culture and ICC become relevant. This first step 
can become a possibility to open spaces for discussion, reflection and implementation of activities focused on the exploration and practice of these concepts in the English language classroom.

Language teachers are called to be promoters of cultures; not only to talk about the target cultures but also to learn about their own. Subsequently, the development of intercultural competence as part of the development of communicative competence should become the daily work of any language teacher. The current world requires citizens more aware of the multiple and diverse cultures around the world. Citizens able to tolerate and understand the others, able to see the differences and to identify the commonalities to be able to construct real communities living in peace and pursuing a common benefit. Thus, citizens consequently constructing scenarios of peace through the languages and cultures.

However, as an advisor of the final practicum space in the undergraduate program of the university where this study took place, I have been able to identify that the lessons proposed by a number of pre-service teachers rarely consider the possibility of opening spaces to put into practice the professional knowledge they have acquired along their studies, including the development of other competences beyond the linguistic one. This may be due to a limitation in the guidance given by the tutors when assigning the topics. I have observed this limitation when pre-service teachers share the topics given by the tutors to plan their lessons. Most of the time, these topics are focused on grammar ones as verbal tenses: present simple, past simple, passive voice, and adjectives, among others. Another reason could be because pre-service teachers are unaware of how they could develop the intercultural competence while steering their classes towards the other competences involved in the communicative competence.

The research study, here described, aimed to recognize what pre-service teachers considered ICC to be as well as their own experiences when proposing activities intended to raise the practice and appropriation of the concepts of culture and ICC in the English as a foreign language (EFL) classroom.

\section{Statement of the Problem}

ICC has been gaining ground in the processes of teaching and learning of languages. Nowadays, more than being proficient in the use of the foreign or second language, language teachers should also seek to produce culturally competent speakers. As an advisor of pedagogical practicum, during four different semesters, I have had the opportunity to observe and analyze the lesson plans that pre-service teachers proposed for the development of the English language class of which they were in charge. From my analysis, I could identify that their lesson plans proposed certain topics related to the development of the linguistic, 
pragmatic, and sociolinguistic competences in English; nevertheless, their main focus was on its grammar and other linguistic aspects. This situation was also identified during my class observations in which I could recognize that these pre-service teachers focused their attention and efforts on teaching certain vocabulary or getting correct grammar use in English from their students.

Starting from that observation and based on the idea that teaching a language is teaching a culture, and that these two concepts cannot be separated as if they were two different dimensions of the same field of knowledge, I considered the need to explore the concepts of culture and intercultural competence that future language teachers held and how they considered they were approaching that competence in their English language lessons. In that sense, I stated the following questions for the research study herein described:

- What knowledge do pre-service teachers have about ICC?

- How do pre-service teachers consider they are approaching ICC in their English language lessons?

\section{Theoretical Framework}

The following is the discussion about the theoretical foundations that support the present study.

\section{From Culture to Intercultural Communicative Competence (ICC)}

The concept of culture has deserved the attention of different theoreticians and authors. It has been defined from two different views: static and dynamic, or in the words of Kramsch (2013), culture with capital $C$ and culture with small $c$. The first one, culture with capital C, refers to "the geography, history, literature and great achievements of a country and its people" whereas the latter concerns "facts having to do with custom, manners, and way of life or life-style" (Bueno, 1996, p. 362). It is this latter on which language teachers are called to focus their attention. As language is a living entity, culture is transformed by means of language. In that sense both are dynamic entities that cannot be separated because teaching a language or speaking a language is the way cultures are represented.

Liddicoat (2002) also stresses the idea that "the static view of culture does not recognize the link between language and culture" (p. 8) whereas "the dynamic view of culture requires learners to actively engage in culture learning, rather than only learning about the cultural information of the target culture in a passive way" (Liddicoat, 2002, p. 8). Additionally, culture is a heritage that permeates life and that remains with us by means of our ways of acting in diverse circumstances or scenarios. Esteban (2014) affirms that: 
We learn those behaviors from our parents, our teachers or from other people who touched or have touched our lives in their different stages. Culture also involves all the beliefs we have about ourselves and the beliefs that others have about us. It means that culture is the result of a process in which people invent and re-invent their lives in order to feel they are part of a community or a social group. (p. 29)

Based on the previous authors' ideas, the role a language teacher plays in the classroom is crucial in terms of providing students with opportunities to reflect upon other cultures while their own representations are questioned, analyzed, and evaluated. Most of the time, culture in the English language classroom has been perceived as the learning and appropriation of facts, customs, and special dates of the target cultures rather than a possibility to explore, contrast, critique, and analyze, from different perspectives, those items of the cultures, including students' own cultures.

The new policies regarding bilingualism in our country consider it to be relevant to develop or include cultural understanding as part of the English language classes. However, most of the time, the cultural practices and products that are presented in the classes focused mainly on the target ones and rarely on the Colombian or Boyacense ones.

According to Liddicoat (2002), culture learning "becomes an engagement with cultural practices rather than exposure to information about a culture and cultural competence to be developed through language learning takes the form of intercultural behavior in and through the language being learned" (p. 8). Kramsch (2013) states that "learning about a foreign culture without being aware of one's own discursive practices can lead to an ahistorical or anachronistic understanding of others and to an essentialized and, hence, limited understanding of the Self" (p. 69). Therefore, language teachers should become mediators between cultures. "If language teachers are able to perceive, understand, and value their own culture and other cultures, they may be able to cope more efficiently with differences in their classrooms" (Ramos, 2013, p. 207).

In the same line of thought, Barletta (2009) claims for the need to think about how English language teachers want to represent themselves in interacting with other cultures and how other cultures are represented in the foreign language classroom. This author states the need to make decisions about how to incorporate the cultural dimension into the curricula or in the standards and how to evaluate it; on the contrary, "we will continue reading and hearing myths about what English can do for the country and its citizens" (Barletta, 2009, p. 154).

The previous ideas are closely connected to what Byram, Gribkova and Starkey (2002) define as the best teacher. For these authors, 
The 'best' teacher is neither the native nor the non-native speaker, but the person who can help learners see relationships between their own and other cultures, can help them acquire interest in and curiosity about 'otherness', and an awareness of themselves and their own cultures seen from other people's perspectives. (p. 10)

Therefore, developing ICC in pre-service language teachers should be mandatory. These new teachers are the ones in charge of opening spaces to place cultures into the language classroom. The result of that new scenario can become one of the opportunities for learners to develop a better understanding of the world and its changes in this new era of globalization and easy access to the information.

There are multiple and varied definitions to describe what intercultural competence involves. Bennett (1993) presents the Developmental Model of Intercultural Sensitivity to describe the evolutionary process that an individual internally follows from the stage of ethnocentrism (one's own culture is central to all reality), to the stage of ethnorelativism (one's own culture understanding in the context of other cultures). The first stage, ethnocentrism, involves sub-stages that Bennett (1993) has defined as denial, defense, and minimization of cultural difference. The second stage, ethnorelativism, presupposes other sub-stages as acceptance, adaptation, and integration of cultural difference.

Although this model presents a linear process for a person to move from a monocultural view towards an intercultural view, it would be difficult to identify in which stage a person is, since human beings' attitudes and behaviors change depending on the circumstances and, even more, on the same personal experiences they have lived or are living. In that sense, one day a person can be very ethno-relativist and able to recognize and value cultural differences; on a different day, the same person can be very ethno-centrist though, feeling that his/her culture is the best and unique referent for the whole world.

Another author that has approached this competence is Deardorff (2006). She proposes a Process Model of Intercultural Competence. This model provides a different idea about the development of the intercultural competence. For this author, this development involves a continuous process different from the linear one proposed by Bennett (1993). Deardorff (2006) considers that the journey is never ending as the learner continues to learn, change, evolve, and become transformed throughout time. This model also denotes the relationship 16 between the personal and the interpersonal interaction levels.

Byram (1997) considers a model of intercultural competence as an essential skill for language teaching professionals. This author proposes a group of competences or 'savoirs' to understand ICC: knowledge (savoirs), attitudes (savoir-être), skills of interpreting and relating (savoir comprendre), skills of discovery and interaction (savoir apprendre/faire), and political education including critical cultural awareness (savoir s'engager). This last savoir or competence is the one that connects and entwines all the other savoirs. This savoir s'engager is developed 
with a constant reflection and identification of the self when compared with others and vice versa. That is why language education and teaching-learning practices are relevant to develop this critical cultural awareness competence and the other ones related to ICC.

Byram (1997) defines each one of the saviors as follows: Knowledge includes learning about social groups, products, practices and processes of interaction. Attitudes involve curiosity and openness towards the other as well as readiness to revise cultural values and beliefs and to interact and engage with otherness. Skills of interpreting and relating mean the ability to identify and explain cultural perspectives and to mediate between, and function in, new cultural contexts. Skills of discovery and interaction are related to the ability to acquire new knowledge about a culture and cultural practices and the ability to operate knowledge attitudes and skills under the constraints of real-time communication. Finally, "critical cultural awareness is defined as the ability to evaluate critically the perspectives and practices in one's own and other cultures" (Byram, 1997, p. 124).

With his model, Byram (1997) invites language learners and teachers to explore and approach the skills, attitudes, and understanding necessary to develop a more reflective and analytical vision into both their own and other cultures. By doing so, both can move beyond the common stereotypes that emerge when cultural issues are approached in language classes.

Since I wanted to identify whether or not the participants' understanding and experiences were related to what Byram (1997) stated as the skills, knowledge, values and attitudes inherent to the ICC, I focused mainly on his model. That was the main reason to consider his model and not the other ones reported previously. Byram's (1997) model can be considered as a framework for the implementation of ICC in the language classroom as it provides teachers with practical ideas to approach the different savoirs.

\section{Culture and Interculturality in the EFL classroom}

Based on the idea that culture and interculturality are more than topics to be approached in the language classes, different researchers and teacher-researchers have been opening rich scenarios where they have involved these two concepts as part of their languages classes, and they have obtained interesting results to promote continued inquiry about culture and its inseparability in the language teaching processes. Some of those experiences are reported here.

Gómez (2012) conducted a study to identify, on the one hand, how EFL learners develop ICC through the study of literary selections and, on the other hand, which teaching approaches might be useful to help EFL learners develop ICC through the study of literary selections. Gómez (2012) could demonstrate that integrating language and literature in English as a foreign language not only constitutes a communicative reading practice, but also the opportunity to construct cultural knowledge through social interaction. 
Rico (2012) also reported an action research study to find out the ways language materials promoted the development of students' ICC. This study evidenced that the savoirs were not developed in the same way and that the dimensions of knowledge and awareness were the ones in which the participants had more disposition. Rico (2012) states that "teaching from an intercultural perspective goes beyond teaching contents. Culture is not easily teachable" (p. 147). That is the reason why materials and especially course books should be adapted by teachers' awareness of their cultural load; on the contrary, the "old school of thought remains the same" (Rico, 2012, p. 147).

Olaya and Gómez (2013) carried out a qualitative research study to explore pre-service English teachers' perceptions of and attitudes toward the aspects of culture and intercultural competence addressed in their English language classes in the undergraduate programs of three Colombian universities. Findings revealed that pre-service teachers are mainly taught elements of surface culture and lack full understanding of intercultural competence. They also see culture as a separate aspect of their future teaching careers.

Ramos (2013) shares a pedagogical experience where she analyzed how intercultural competence skills emerged in pre-service teachers after the implementation of an intercultural component in a Research and Pedagogy class. The author identified that pre-service teachers started to develop intercultural competence by developing skills to interpret and contextualize cultural practices and by raising awareness of contextual complexities.

These four Colombian studies were the basis I considered for approaching my study. They were also relevant because they provided me with insightful ideas about the importance of involving and approaching our classes in the exploration of other competences that are part of the communicative competence and that are required to become citizens of the world.

\section{Pre-service Teaching}

According to Schön (as cited in Wallace, 1991), pre-service teaching is "the stage where beginning teachers obtain substantial on-campus course work that they expect to transfer directly to their practicum settings, where they begin to act as a teacher" (p. 13). In the institution where the study was conducted, during the pre-service teaching experience, language student teachers are assigned at least one cooperating teacher or tutor from the school where the teaching practicum takes place. Pre-service teachers can serve as a novice teacher practicing the art and craft of language teaching by working with actual learners and performing teacher-related duties. A university practicum director or advisor works with the pre-service teachers and the cooperating teacher in order to enrich the practicum and guide the student teachers towards the construction and exploration of pedagogical and 
methodological tools. The cooperating teacher and the Practicum advisor serve as both guides and evaluators, completing formative and summative reports of pre-service teachers' achievements or areas for improvement.

In this sense, pre-service teachers are always experiencing what they learned and identifying possibilities to enrich their practicum and their future as professional teachers. During this stage in their life as student teachers, they face different processes; they care about what to teach, how to teach, where to teach, and whom to teach (Huertas, 2014).

\section{Research Method}

To answer the research question and to achieve the objectives stated, I conducted a descriptive case study. According to Merriam (2009), a descriptive case study report "provides a detailed account of the phenomenon under study" (p. 27) and a "rich, thick description of the phenomenon under study" (Merriam, 2009, p. 43).

The participants were five female pre-service teachers developing their final practicum at a public school in Tunja. They were working with preschoolers and primary learners from different grades: pre-school to sixth grade. The pre-service teachers were developing their final pedagogical practicum in teaching English. As a researcher, I was concerned with the protection of my participants' personal identity and the data collected from them. In that sense, I designed a consent form that these participants knew about and signed before starting the research process. In that letter, they were invited to participate in the research and were informed about their roles, risks, anonymity, confidentiality and privacy considering the information they provided. They also stated a pseudonym to identify themselves: Ana, Camila, Perla, Vanessa, and Luisa.

With the intention of gathering the information to answer the research questions, I analyzed the lesson plans they proposed; then, I applied one survey and one semistructured interview.

\section{Document Collection}

These are the sets of documents relevant to the research context (Burns, 1995). In this study in particular, the lesson plans that the pre-service teachers designed were considered as to whether or not they approached ICC in their classes.

\section{Survey}

According to Marshall and Rossman (2011), the purpose of a survey is "to learn about the distribution of characteristics, attitudes, or beliefs of participants" (p. 129). The survey applied during this research study was designed and implemented to identify how 
the participants defined and characterized the term ICC and the skills or knowledge they considered a language teacher should have to become a mediator of cultures.

\section{Semi-Structured Interview}

An interview was applied at the end of the process in order to collect more data about their intercultural experiences as well as their opinions and perceptions about ICC. This was a face-to-face verbal session. I had planned some questions in advance; however, some other questions emerged along the interview. I invited the participants to hold a 10-minute interview to clarify some answers they had provided in the surveys and with the intention of sharing their personal and professional experiences and understandings regarding the ICC. DeMarrais (as cited in Merriam, 2009) defines an interview as a "process in which a researcher and participant engage in a conversation focused on questions related to a research study" (p. 87).

\section{Data Analysis and Findings}

A process of triangulation was done with the intention of giving validity and reliability to the research process. This triangulation was conducted by using multiple sources of information (Freeman, 1998). Denzin (1970, as cited in Cohen \& Manion, 1995) describes different types of triangulation: time triangulation, space triangulation, combined levels of triangulation, theoretical triangulation, investigator triangulation, and methodological triangulation. The methodological triangulation uses either the same method on different occasions, or different methods on the same object of study.

In this particular study, a methodological triangulation was implemented with three data collection instruments. According to Merriam (2009), there are three phases for approaching the data analysis: data preparation, data identification, and data manipulation. During the data preparation, I read and analyzed the different lesson plans that my students presented weekly and I identified that they were not planning activities that focused on the ICC. Therefore, I decided to apply a questionnaire to identify whether or not those pre-service teachers were aware of that competence and the way they defined and characterized it. I also prepared and organized a semi-structure interview to go deeper into their experiences, opinions and perceptions towards ICC.

During data identification, I looked for the information that I considered was giving an answer to my research question and my research objectives. In that sense, I identified common patterns in the information collected with the three instruments. Finally, I highlighted sentences, comments, and expressions that were common or similar in the survey as well as in the interview. During this last stage, data manipulation, I used small pieces of paper of different colors to differentiate and identify the information collected. Based on the previous 
data analysis process, I could establish the next categories that constitute the answers to my research questions.

\section{The Tip of Which Is Visible From Others}

Although ICC was not proposed explicitly in their lesson plans, as they did not include any activity mainly towards this competence, it was possible to identify that participants considered this competence as an ability required to be learned through an interaction with other cultures. They understood this competence considering only the superficial issues related to the iceberg concept of culture (Brembeck, as cited in Lázár et. al., 2007, p. 7). To this concept, culture has been compared to an iceberg, because much of what is related to culture is undetected, similar to an iceberg where the biggest part is under the surface. Regarding culture, a good number of cultural practices and products, although invisible, should also be approached by language teachers interested in developing ICC.

Their answers as to how they defined and characterized the term of ICC pointed to common aspects related to sharing cultural experiences and to understanding customs from other countries rather than to more complex situations in which people could be involved in an intercultural situation as relativizing the others' behaviors or beliefs or evaluating one's and others' cultural practices and products. These situations can involve definitions of appropriateness, beauty, and respect, among others, as well as the values each particular culture has regarding abstract concepts like love, death, and respect. A number of the participating pre-service teachers' answers pointed towards these superficial issues related to the ICC. Some of their answers were:

I believe that Intercultural Communicative Competence is a way to learn through the interaction between other cultures, also as a way to know and share cultural experiences. (Ana. Survey. Q1)

Noting the same aspect, Lucía reported,

I define the ICC as a competence to communicate successfully with other cultures, understanding the different customs. (Survey. Q1)

In the same question, Camila wrote:

ICC is a way when the students can talk and transmit different ideas about their own and different customs. It is an interesting and attractive idea for practicing other languages. (Survey. Q1)

Ana and Perla also commented on the same issue:

It is an ability that allows to communicate and understand cultures in different ways. (Ana. Survey. Q3) 
I think that it is when I have the contact with people of other countries and we can interchange the customs. (Perla. Survey. Q1)

These accounts revealed how most of the participants refer to the word customs as an important issue of the ICC to be addressed in the language classroom. These answers exposed that although they were able to provide a definition to the concept of ICC, they largely focused only on the superficial level of the iceberg of culture. It can also be said that, regarding Byram's (1997) theory, which supports this study, the participants could be placed in the savoir faire since they considered knowing from others to be a requirement to become interculturally competent.

Additionally, their definitions scarcely account for the possibilities that they, as preservice teachers, and their students could have to approach a critical analysis of cultures, cultural practices, and cultural products involved in the language learning and teaching processes. This analytical practice is what can enrich and transform the language class into a space to learn from others and to evaluate who each one is and where each is in the current world.

During the same survey, it was possible to identify that the participants considered it necessary to develop the ICC with the aim of learning and interacting with people from other cultures or from other countries. For example, Perla says:

I understand this concept like a process of learning, through this [] the students can improve their learning and at the same time they can do an intercultural interchange to learn about other cultures and they can transmit their own knowledge. (Perla. Survey. Q3)

Considering the same issue, Lucia reported:

I think that is a concept created to improve the knowledge about other cultures, sharing with people who are from other countries. [sic] (Survey. Q3)

Camila highlighted the importance of identifying differences among cultures:

To be aware that each culture has many differences and some points as accents, idioms and something like that. (Survey. Q3)

22 During the interviews, when the participants were asked about the aspects of culture that they considered most important to be approached in teaching a foreign language, they evidenced the learning about other cultures, too. Their answers were very similar and most of them pointed towards the same topics related to the visible aspects of the iceberg of culture. In this sense, Lucia for example said:

The beliefs because it helps us to understand and communicate in a good way with the other people. (Interview) 
Pre-Service Language Teachers' Knowledge and Practices of Intercultural Communicative Competence

Similarly, Camila and Perla commented:

I think customs, food, religion, and music". (Camila. Interview)

Maybe customs, food, holidays to make a comparision between both. [sic] (Perla. Interview)

Vanessa highlighted the importance of knowing those aspects of culture to learn from others:

Customs, idioms, because those things are important to know about another culture, the customs are different in each country. (Vanessa. Interview)

The concept of ICC held by these participants can also be situated in the savoir (knowledge) proposed by Byram (1997). All of them considered social groups and their products and practices as essential elements to be approached in intercultural encounters. It can be stated that these participants likely perceived this competence as a one-way process; none of them mentioned the need to include the cultural practices and products from their home country as part of the competence.

On the other hand, during the interviews, too, when they were asked about the opportunities that they created for their students to understand and experience other cultures, their answers pointed to the use of videos or other audiovisual aids as resources to support these issues during their lessons. In this sense, for instance, they said:

In some cases, they have contact with other cultures through videos, movies, and if we could meet foreign people. (Camila. Interview)

Perla also reported:

The use of audiovisual materials can help them to understand the way other cultures live. (Interview)

To synthesize this category related to pre-service teachers' knowledge about ICC, according to their answers, this competence is more concerned about the possibilities they can create to foster knowledge about or from other cultures than being related to the development of skills and values.

Considering that the development of ICC is a never-ending process, with more opportunities to explore this concept, pre-service teachers may be able to enrich their current teaching practices and become better mediators between cultures. These pre-service teachers can develop abilities and competences to identify differences and similarities among cultures and to state critical positions in front of the variety of cultures that can come into contact when any language learning process takes place. 
Therefore, the foreign language program should define or design a more intercultural curriculum so that its pre-service teachers can have ampler possibilities to reflect, conceptualize, and experience, based on different theoreticians and researchers. Thus the inclusion of the other saviors or knowledge could enrich the language teaching practice towards a more intercultural approach that really connects language and culture.

To sum up, I want to highlight Ramos (2013), Barletta (2009), and Gómez (2012) who consider it fundamental that teachers (pre- or in- service) constantly reflect on whose knowledge, whose culture, and whose ideas they are sharing with their students. Jokikokko (2010, p. 27.) states that an ideal is that the school supports the identity and culture of all students and creates a safe and equal learning environment for all, rather than only for those who belong to the so-called mainstream.

The next finding is connected to the participating pre-service teachers' traditional view of culture for the English language class. This view considers culture as something that can be separated from the usual topics developed in the English language classroom; therefore, approached in isolation as if its implementation were another source to change the mood or the taste of the class. This is the reason why I have called this category $A$ Dressing for the Class.

\section{A Dressing for the Class}

Regarding this second category, I identified that the pre-service teachers considered it necessary to know more about ICC in order to enrich their English language lessons and to provide their students with more possibilities to increase their cultural knowledge. In this sense, when they were asked about the importance that they attached to teaching the ICC compared to other grammar topics, vocabulary, or the four basic language skills, they reported:

The intercultural communicative competence is very important because the learning of a foreign language includes the understanding of the situations where the speaker is involved. The social interaction is the aim of the language, in that way the culture involves all the activity of the human being. [sic] (Camila. Interview)

Luisa also commented around this issue and the need of connecting all the teaching process to the English skills as well as to the ICC:

I think that everything has to be connected with the English skills and the Intercultural Competence because we need to create a link between both, and also that could improve the knowledge about other cultures ['] teaching process. [sic] (Luisa. Interview)

Additionally, Ana reflected on a possible mistake she was making because she had not approached that competence in her classes: 
I don't use that competence. Maybe that is a mistake because we need to share the other cultures with our students and make that they like to know about it. We use to teach just grammar and vocabulary. [sic] (Ana. Interview)

For Perla, knowing a culture can help to learn a language; then, she reported:

I consider it is necessary because the culture is an important piece in the language. In that way knowing the culture let us to learn better a language. [sic] (Perla. Survey Q5)

Ana considered that involving the ICC in her classes could guide her to have more interesting, interactive, and creative lessons:

It is an interesting and creative idea in an English class. It helps to motivate to students in the class, since the topics can be interesting for them and promotes the participation in the class. [sic] (Ana. Survey. Q5)

Luisa also regarded that by working on this competence students would be able to understand and adapt to other cultures.

Students need to have knowledge in relation with this term to develop and understand each culture and to adapt to any culture. [sic] (Luisa. Survey. Q5)

The pre-service teachers also consider it necessary to give more attention to this competence since during their undergraduate studies they were not given enough opportunities to explore what the competence involved in terms of intercultural knowledge, skills, attitudes, and values. During the interview, they were asked about the importance of placing emphasis on the ICC; some of their answers were:

I think the intercultural competence should be given more emphasis in language teaching because it is necessary if we want to be an integral teacher. (Perla. Interview)

Similarly, Luisa reported:

I think that in foreign language teaching we should give more emphasis because the importance to know foreign cultures and foreign people could help to improve skills and cultural knowledge. (Luisa. Interview)

Considering the benefits this competence has, Ana expressed:

I think this competence has many benefits to learn a foreign language, the student can learn cultural aspects that reinforce or help to introduce some topics, grammar, writing among other. [sic] (Ana. Interview)

Camila perceived the competence as a complement for her studies:

I think that ICC is an important part to complete my career. (Camila. Interview) 
By reading and analyzing these pre-service teachers' statements, I can say that these participants consider it important to approach the ICC in their lessons, although this competence is for them an entity that can be separated and developed in certain specific moments of their lessons. In that sense, I may state that that they consider this competence as a fifth language skill. In comparison to what Kramsch (1993) claims as the fifth language skill, it is for a different position of language regarding culture. This author states the urgent need of conceiving language as a social practice, therefore "culture should become the core of language teaching to the extent that cultural awareness should be viewed as enabling language proficiency" (Kramsch, 1993, p. 8). Regarding the same consideration, Byram et al., (2002) state that:

What language teachers need for the intercultural dimension is not more knowledge of other countries and cultures, but skills in promoting an atmosphere in the classroom which allows learners to take risks in their thinking and feeling. Such skills are best developed in practice and in reflection on experience. (p. 34)

The previous concepts argued not for a complete and perfect competence, but for the need of opening spaces to identify the existence of diverse cultures. The concepts also argued for the relevance of reflecting upon cultures by assuming critical positions and not merely displaying a passive acceptance of promoting certain knowledge without considering its veracity and reliability.

Based on the previous concepts and the information collected during the study, it is possible to conclude that pre-service teachers identify certain aspects related to ICC, although they still lack a reasonable appropriation of the concept to become the cultural mediators that the current world requires. Nevertheless, I could say that they are taking their first steps on the long road of their life as professional teachers since they have the attitude to understand and accept people from other cultures which is the foundation of intercultural competence (Byram et al., 2002).

The analysis of data led me to identify the relevance of promoting activities and opportunities for pre-service teachers to have the possibility to reflect on and learn from other cultures so that they can discover that they are also part of a culture that deserves to be analyzed and studied in their language lessons. In this sense, what we, teacher educators or practicum advisors, can do is to open spaces to ask more questions related to cultural practices and products of pre-service teachers in their lesson delivery.

Language teachers do not need to have a diploma that certifies they are interculturally competent; however, it is necessary to guide them to identify that the current world requires more responsible decisions about what language teachers are doing or proposing to develop in their classes. The new language teachers should be aware that their classes can be approached to foster the development of the skills, knowledge, and values that learners 
require to understand the existence and respect of those others outside the four walls of their classrooms.

\section{Conclusions}

This study was designed to recognize what knowledge a group of pre-service teachers had about ICC and how they considered they were approaching it in their lessons. They were invited to answer a series of questions in a survey and to participate in a semi-structured interview that comprised the sources to answer the research question. The data collected by means of students' lesson plans, interviews, and the survey revealed that their understanding of ICC is more related to the savoirs knowledge and faire than to the others savoirs proposed by Byram’s (1997) model.

While participants answered the questions and participated in the interview, they were talking about their experiences as pre-service teachers with situations they considered to be related to ICC. Their understanding of this competence is more connected to the traditional view of culture since they were referring mainly to customs and ways of living in other countries rather than their involvement in more critical activities in which they could reflect on other types of cultural issues. The same issues that sometimes are not easy to be approached in the language classroom.

This was also the opportunity to recognize that these participants have not had enough opportunities to become involved in situations more favorable to develop the ICC since their classes at university were approached toward other aspects of the communicative competence. However, from the data analysis I could identify that they were on the road to continue learning more about this competence. I also saw that they were aware of the need of giving their grammar-based lessons a different orientation that requires also the development of other competences as the intercultural one as well.

At the end of the study, my participants recognized the importance of gaining more knowledge about how to approach ICC in their lessons. They were also able to identify their role as cultural mediators who not only communicate information but also should develop better social relationships with people of other cultures and languages. However, they recognized that this role requires more practice and more commitment with the English language classes which they will have in their future professional life.

On the basis of this research, it seems that pre-service teachers were aware of ICC, but they lacked opportunities and theoretical support to bring this competence into practice. It is necessary for the language program in this institution to think of alternatives to provide students with more opportunities to explore, learn, and inquire about this competence; alternatives that go beyond the perfect language speaker and that are a requirement in the 
current globalized world. These alternatives require the revision of the different syllabuses proposed for the English courses to propose a more intercultural language teaching approach; what is more, the didactics classes should also include information and practice about how teachers and researchers around the world have implemented ICC in their teaching practices. For me, as a researcher and a teacher educator, I realize that pre-service teachers make their best efforts to plan their lessons, but sometimes they are limited by their practicum advisors because they have to prepare their lessons based on what their advisors ask. The pre-service teachers have their hands tied as to proposing other activities to involve their students in different scenarios that could enrich both their practicum and students' knowledge.

\section{References}

Barletta, N. (2009). Intercultural competence: Another challenge. Profile: Issues in Teachers' Professional Development, 11(1), 143-158.

Bennett, M. J. (1993). Towards ethnorelativism: A developmental model of intercultural sensitivity. In R. Paige (Ed.), Education for the intercultural experience (pp. 21-71). Intercultural Press.

Bueno, A. (1996). Sociolinguistic and sociocultural competence, in N. McLaren \& D. Madrid, A Handbook for TEFL (pp. 345-373). Alcoy Marfil.

Burns, A. (1995). Teacher researchers: Perspectives on teacher action research and curriculum renewal. In A. Burns \& S. Hood (Eds.), Teacher's Voices: exploring course design in a changing curriculum (pp. 3-20). National Centre for English Language Teaching and Research.

Byram, M. (1997). Teaching and assessing intercultural communicative competence. Multilingual Matters.

Byram, M., Gribkova, B., \& Starkey, H. (2002). Developing the intercultural dimension in language teaching. Council of Europe.

Cohen, L., \& Manon, L. (1995). Research methods in education (4 ${ }^{\text {th }}$ ed.). Routledge.

Deardorff, D. K. (2006). Identification and assessment of intercultural competence as a student outcome of internationalization. Journal of Studies in International Education, 10(3), 241-266. https://doi/10.1177/1028315306287002

Esteban, M. (2014). Exploring critical literacies in a literature and culture class. Enletawa Journal, 7, 23-40.

Freeman, L. (1998). Doing teacher-research: From inquiry to understanding. Heinle \& Heinle.

Gómez, L. (2012). Fostering intercultural communicative competence through reading authentic literary texts in an advanced Colombian EFL classroom: A constructivist perspective. Profile: Issues in Teachers' Professional Development, 14(1), 49-66.

Huertas, A. (2014). Pre-service teachers' understandings of teaching culture in an EFL class [Unpublished Master's dissertation]. Universidad Pedagógica y Tecnológica de Colombia.

Jokikokko, K. (2010). Teachers' intercultural learning and competence [Unpublished doctoral dissertation]. The University of Oulu. 
Kramsch, C. (1993). Context and culture in language teaching. Oxford University Press.

Kramsch, C. (2013). Culture in foreign language teaching. Iranian Journal of Language Teaching Research, 1(1), 57-78.

Lázár, I. et al. (Eds.) (2007). Developing and assessing intercultural communicative competence: A guide for language teachers and teacher educators, Languages for Social Cohesion. Council of Europe Publishing.

Liddicoat, A. (2002). Static and dynamic views of culture and intercultural language acquisition. Babel, 36(3), 4-11.

Marshall, C., \& Rossman, G. B. (2011). Designing qualitative research. Sage.

Merriam, S. B. (2009). Qualitative research. Jossey Bass.

Olaya, A. \& Gómez, L. (2013). Exploring EFL pre-service teachers' experience with cultural content and intercultural communicative competence at three Colombian universities. Profile: Issues in Teachers' Professional Development, 15(2), 49-67.

Ramos, B. (2013). Towards the development of intercultural competence skills: A pedagogical experience with pre-service teachers. HOW Journal, 20, 206-225.

Rico, C. (2012). Language teaching materials as mediators for ICC development. Signo y Pensamiento, Documentos de investigación, 30, 130-154.

Wallace, M. (1991). Training foreign language teachers: A reflective approach. Cambridge University Press. 